\title{
Optimum Values of Tank Volume to Collector Area Ratios of Thermosyphon Solar Water Heaters for Libyan Families
}

\author{
M. J. R. Abdunnabi \\ Center for Solar Energy Research and Studies, Tajura, P. B. Bar 12932 Tripoli \\ e-mail: mols jum a yahoo com
}



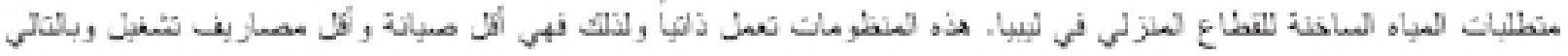

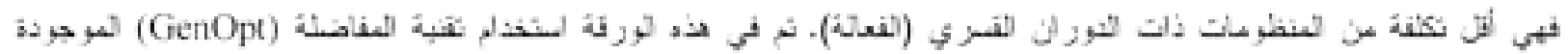

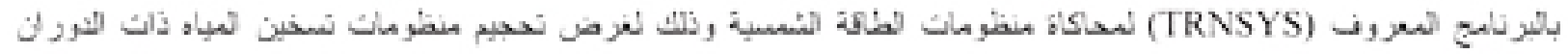

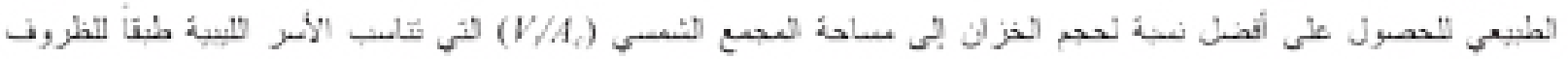

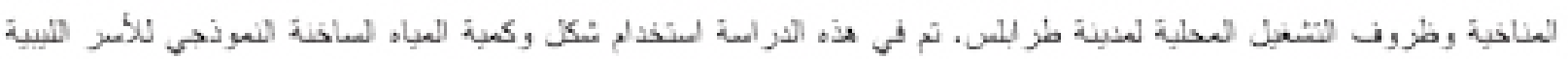

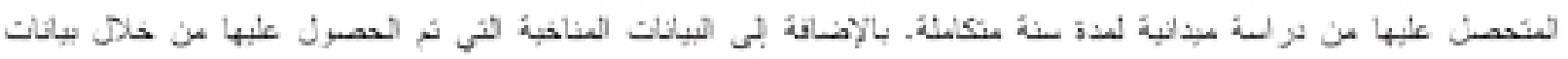

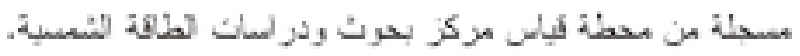

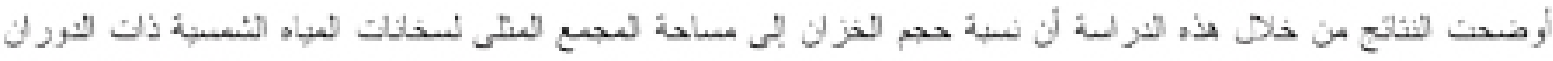

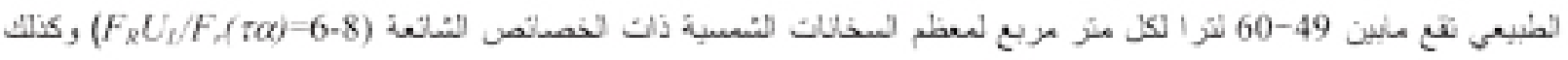

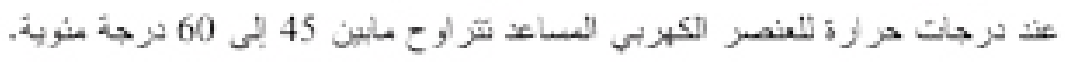

Abstract - Thermosyphon solar water heaters are the best choice to be utilized in residential sector to provide the required hot water in Libya. These systems are autonomy in operation and as a result require less maintenance, and hence low operation and initial costs than active systems. In this paper, GenOpt optimization technique provided in TRNSYS simulation program is used for sizing thermosyphon systems to obtain the optimum size (namely $V / A_{\varepsilon}$ ratio) of thermosyphon systems that suits Libyan families according to the weather and operating conditions of Tripoli. The typical hot water load pattem and quantity of the Libyan families are taken from a field study conducted on a number of solar systems for a whole year. Whereas, the typical weather data are taken from five year measurements recorded at CSERS weather station.

The results showed that the optimum storage tank volume to collector area ratio of thermosyphon systems is between $49-60 \mathrm{Lit} / \mathrm{m}^{2}$ for the most common collector characteristics ratio $\left(F_{R} U_{L} / F_{r}(\tau \alpha)-6-8\right)$ and the auxiliary heater set point temperature ranges from (45-60 $\left.{ }^{\circ} \mathrm{C}\right)$.

Keywords - Thermosyphon solar water heater, TRNSYS, Optimization.

\section{INTRODUCTION}

A huge number of houses are being built every year in Libya in a governmental plan to build more than 250 thousand homes by 2012. More recently, new laws were expected to impose using solar water heaters instead of using electric ones wherever possible in the new buildings. Great potential of investment in solar water heaters is expected to take place in the next 
few months as a result of many buildings are ready for installation of such systems. Therefore, care should be taken to put control on solar water heating systems market to offer good quality systems. Hence, this will reflect the good image on reliability of these systems in providing the required hot water for buildings.

Today, there are several types of solar water heaters in use worldwide, and the most common of these systems is the thermosyphon type. These systems are more suitable for warm regions where the winters are mild and therefore liquid freezing is not an issue. Well designed thermosyphon systems have the advantage over the other types of systems: less investment cost, less operating and maintenance costs. Therefore, these systems are very adequate for the Libyan climate.

Literature review has revealed that there is no systematic easy method for sizing and optimizing thermosyphon systems, and most of the systems in the market were designed based on trial and error methods which are more based on intuition rather than scientific methods [1]. This could be attributed to the fact that modeling the thermosyphon phenomena in these systems is a very complicated task.

The storage tank volume to the collector area ratio is one of the main design parameters of the solar water heaters. Through the literature many propositions have been suggested to determine the optimum ratio. Shariah and Löf [2] have found the optimum value of $V_{r} / A_{c}$ in thermosyphon systems according to the weather conditions of Los Angeles to be 40 $\mathrm{Lit} / \mathrm{m}^{2}$ in case of the daily hot water drawn being 250 litres at temperatures of $50-$ $80^{\circ} \mathrm{C}$ and according to the well-known Rand hot-water distribution profile. In Darwin, Australia where there is good solar radiation, the recommended value of the tank to collector ratio is around $112 \mathrm{Lit} / \mathrm{m}^{2}$ for $100 \%$ solar fraction, while in Melbourne, where solar radiation is intermittent and the system is supplied with auxiliary heater, the recommended ratio is around $67 \mathrm{Lit} / \mathrm{m}^{2}[3]$.
Recently, Abdunnabi et.al. [5] have developed an accurate design tool for sizing thermosyphon systems using genetic algorithm optimization routine coupled with the TRNSYS simulation program. The design tool was implemented to find the optimal system design of thermosyphon system for Tripoli-Libya, and for Birmingham-UK. The study gives encouraging results although some of the input data such as hot water load pattern and material cost are not very accurate. The present study focus on using TRNSYS optimization component to find the optimum storage tank volume to collector area ratio for a single family house based on more accurate weather and operating conditions for different configurations. The cost function is used as an objective function for the optimization

\section{HOT WATER LOAD VOLUME AND PATTERN}

In fact, there is a lack of information about the hot water load pattern and volume for Libyan families due to the required facilities to conduct such a study in a large scale. However, in this study, the hot water load pattern and volume are extracted from real measurements of only five solar water heaters fitted for families in Tripoli to evaluate their thermal performance for a whole year [6]. The systems were provided with digital flow meters and temperature sensors scanned every 10 seconds and recorded the data as an average or accumulation (depending on the type of the parameter) for every 30 minutes (user settings). The results obtained for the five systems as quantities of water and their temperature at every 30 minutes are unified as energy before they compiled and accumulated. The accumulated energy over the time of the day as hourly values is converted to water quantities at withdrawn temperature of $45^{\circ} \mathrm{C}$ which is sufficient for bathing and kitchen use. The final result for the typical hot water load pattern for Libyan families in Tripoli is shown in Figure 1. The study has shown that the quantity of hot 
water per person per day is about 57 liters at withdrawal temperature of $45^{\circ} \mathrm{C}$. The typical load profile shows peaks at moming time indicating household bathing practices.

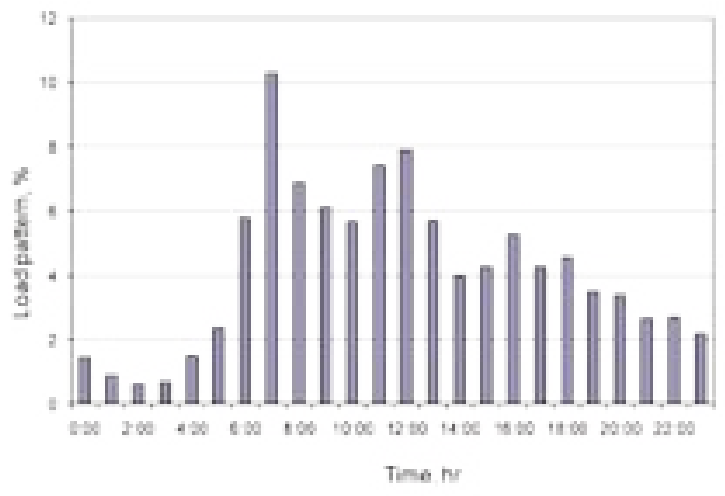

Figure 1: Typical hot water load pattern for Libyan families in Tripoli

\section{WEATHER DATA}

The most important information to run the design tool is the weather data of the location. The weather conditions are inherently changeable, never be days alike in all aspects. Therefore, the typical metrological year (TMY) is the best format used to represent the recurrent prevailing weather data in a certain location. However, due to the dramatic changes of the environment as a consequence of global warming and other issues, the TMY for data collected 30 years ago cannot be considered accurate, and therefore the new measurements will be more representative. In this study, recent recorded weather data from weather station belonging to the Center for Solar Energy Research and Studies (CSERS) located in Tajoura (Tripoli suburb) for five years are used. The data were recorded every 10 minutes for a number of environmental parameters. The methodology used here to extract the representative year is nearly the same as given by Klein[3] for his design year method. Simply by taking the data of the line that has the closest values (the least deviation) of the global solar radiation on horizontal surface and the ambient air temperature to the mean values of the same parameters for the five years. By using this method, a design year of weather data of Tajoura is obtained as shown in Figure 2.

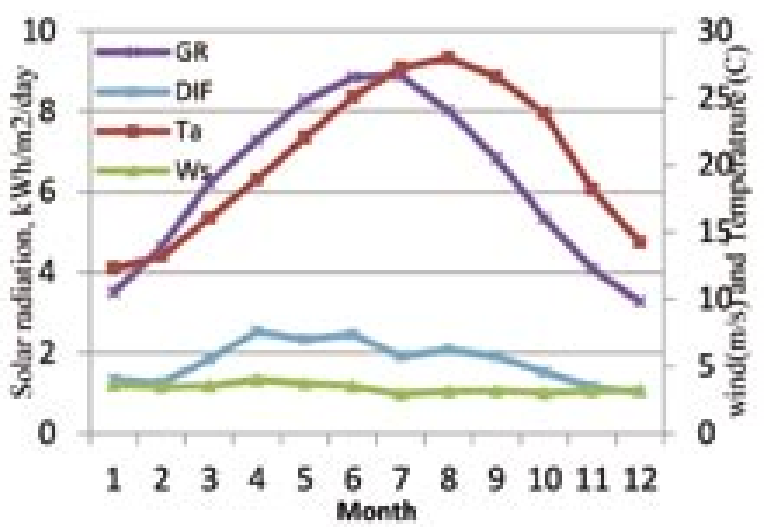

Figure 2: Typical weather data for Tajura (suburb of Tripoli)

\section{TRNSYS MODEL}

TRNSYS simulation program [4] is a very powerful tool for designing and evaluating the long term thermal performance of thermosyphon solar water heaters and studying the effect of its design parameters. The basic idea of TRNSYS is based on modeling each component in a system as module. The program in TRNSYS comprises many subroutines that model subsystem components. The subsystem components included in the standard library are programmed in the FORTRAN language. The program provided with a component Type 45 "thermosyphon collector component" is used in this study with many other components to simulate the operation of actual thermosyphon system as shown in Figure 3.

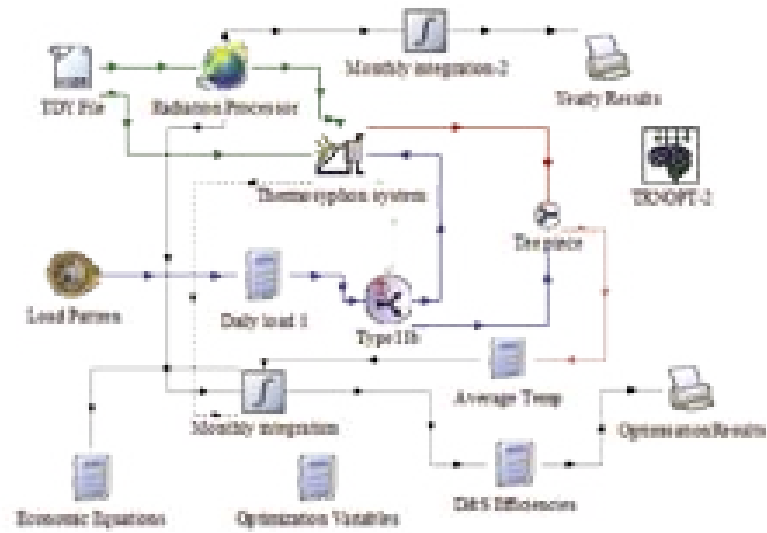

Figure 3: Schematic of thermosyphon system and other components in TRNSYS 


\section{OPTIMIZATION}

In this study, a single objective optimization technique provided in TRNSYS program based on a very famous GenOpt optimization routine through the interface TRNSYS component "TRNOPT" is used. The cost function is chosen as the objective according to the following:

$$
\begin{aligned}
\operatorname{Cos}_{\text {function }}= & A_{C} \times C_{A}+V_{t} \times C_{v}+L T \\
& \times\left(\frac{Q_{\text {ele }}}{3600}\right) \times C_{\text {ele }}
\end{aligned}
$$

Where

$C_{A}$ : cost of the collector per unit of area

$C_{V}:$ cost of the storage tank per unit of volume

$Q_{\text {eie }}$ : annual auxiliary heating rate

$L T$ : expected life time of the solar system

$C_{\text {eie }}:$ is the cost of the electricity

\section{$A_{\text {c }}:$ collector area}

The most important typical values used in this particular study are listed in Table 1.

Table 1: Typical finance and design parameter

\begin{tabular}{|c|c|c|c|}
\hline No & $\begin{array}{c}\text { Design } \\
\text { parameter }\end{array}$ & Value & Remarks \\
\hline $1-$ & $A_{C}\left(\mathrm{~m}^{2}\right)$ & $1 \cdot 5$ & $\begin{array}{l}\text { increment is } \\
0.1 \mathrm{~m}^{2}\end{array}$ \\
\hline 2. & $V_{t}\left(\mathrm{~m}^{3}\right)$ & $0.07-0.38$ & $\begin{array}{l}\text { increment is } \\
0.01 \mathrm{~m}^{3}\end{array}$ \\
\hline 3. & $F_{R} U_{L} / F_{r}(\tau \alpha)$ & $6-8$ & \\
\hline 4. & $C_{4}\left(\mathrm{~L} . \mathrm{D} / \mathrm{m}^{2}\right)$ & 200 & \\
\hline 5. & $C_{Y}\left(\mathrm{~L}, \mathrm{D} / \mathrm{m}^{3}\right)$ & 450 & \\
\hline $6=$ & $C_{\text {rit }}(\mathrm{L} . \mathrm{D} / \mathrm{kWh})$ & 0.05 & \\
\hline
\end{tabular}
values used in the study

It is very important to mention that the unconstrained single objective optimization technique is not the good option to find the optimum system design parameters as the problem is inherently multi-objective, and therefore it is very difficult to get consistent results for different cases to make some sort of comparison. This is attributed to the fact that there is no control on the other objective functions or constrains. In our case, the objective function is the cost, and the other two objective functions are the solar fraction and the user outlet temperature. We can control the output temperature to the user (as an advantage of the TRNSYS, not the optimizer), but it is very difficult to put constrains on the system solar fraction. Although, we still be able to get some very useful information through the use of this routine. Results obtained are presented next.

\section{RESULTS AND DISCUSSION}

\subsection{Tank volume to collector area ratio}

Looking at commercial solar water heaters and the literature, you will find different tank volume-to-collector area ratios $\left(V / A_{c}\right)$. This may be attributed to many reasons such as prevailing weather conditions, system size, operation condition and the required solar fraction.

The optimum tank size according to the hot water demand and the tank volume-tocollector area were investigated, and the results are presented in Figure 4 for the case of $F_{R} U_{L} / F_{r}(\tau \alpha)=7$ and for a solar fraction over $93 \%$, whereas Figure 5 shows the results for the case of $F_{R} U_{L} / F_{r}(\tau \alpha)=6$ and for a solar fraction ranges from $84 \%$ to $85 \%$.

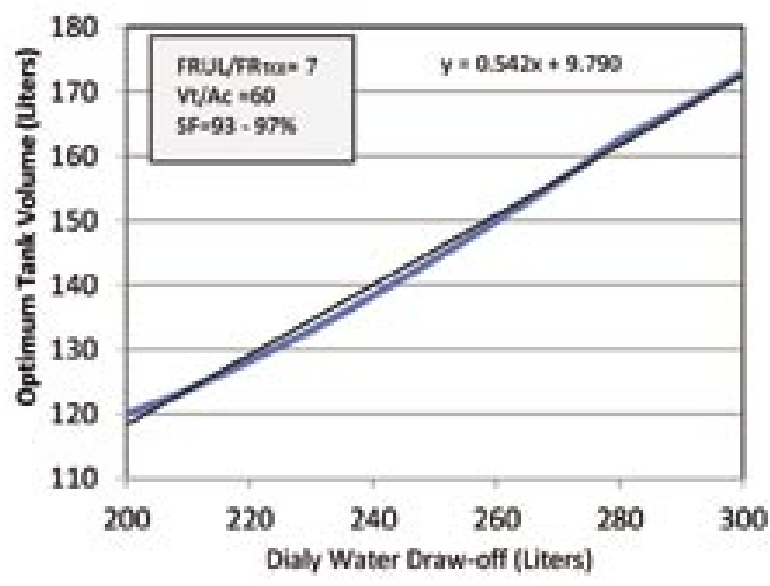

Figure 4: Optimum tank volume versus hot water load volume 
From the results, it is clear that the optimum tank volume is always less than the daily hot water load volume in case of the temperature of water withdrawn is 45 ${ }^{\circ} \mathrm{C}$. In both figures (results) the optimum tank volume to collector area was found equal to 60 liters per square meter, however, the values of system solar fraction and collector characteristics performance ratio are different. These figures are very useful to determine the solar system size based on the hot water demand, system characteristic performance and the required solar fraction.

Actually, this result $\left(V / A_{c}=60\right)$ observed in this study is in good agreement with the results of many other studies.

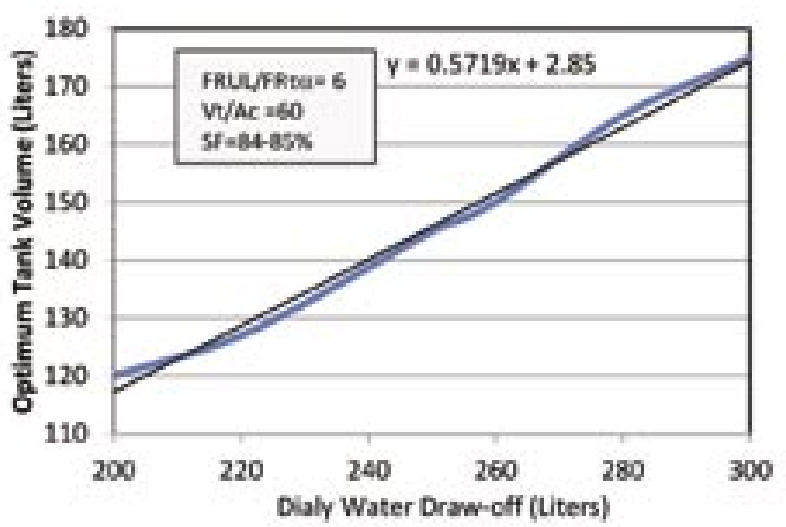

Figure 5: Optimum tank volume versus hot water load volume

\subsection{Effect of user temperature}

The required hot water temperature is very crucial for designing solar thermal systems. It is very important to consider the end use temperature to design the most costeffective system. In this section we will discuss the impact of user temperature variation in case of keeping the same amount of energy demand $\left(Q_{d}\right)$ through varying the amount of water, and considering the auxiliary heater set point temperature the same as the user temperature as following:

$$
\begin{aligned}
& Q_{d}=m_{1} C_{p}\left(T_{\text {user } 1}-T_{c}\right) \\
& =m_{2} C_{p}\left(T_{\text {user } 2}-T_{c}\right) \\
& =\text { const. }
\end{aligned}
$$

Where:
$T_{\text {wer } 1,}, T_{\text {wer } 2}$ : the desired user temperatures (in this case $T_{\text {toerl }}=45^{\circ} \mathrm{C}, T_{\text {wer } 2}=55^{\circ} \mathrm{C}$ )

$m_{l}, m_{2}:$ The equivalent amount of water to satisfy the energy demand in each case.

\section{$C_{p}$ : The specific heat of the water}

Figure 6 shows the effect of the user temperature on the optimum system size. It is very clear that increasing the user temperature (and keeping the same amount of energy required) will increase the system size and hence the system cost. From Figure 6 for the case of daily hot water required 200 liters at $45^{\circ} \mathrm{C}$ (main $\mathrm{x}$-axis scale) which is equivalent to 142 liters at 55 ${ }^{\circ} \mathrm{C}$ (additional $\mathrm{x}$-axis scale), the optimum tank volume is increased by 1.2 times due to the increase of user temperature from 45 to 55 ${ }^{\circ} \mathrm{C}$

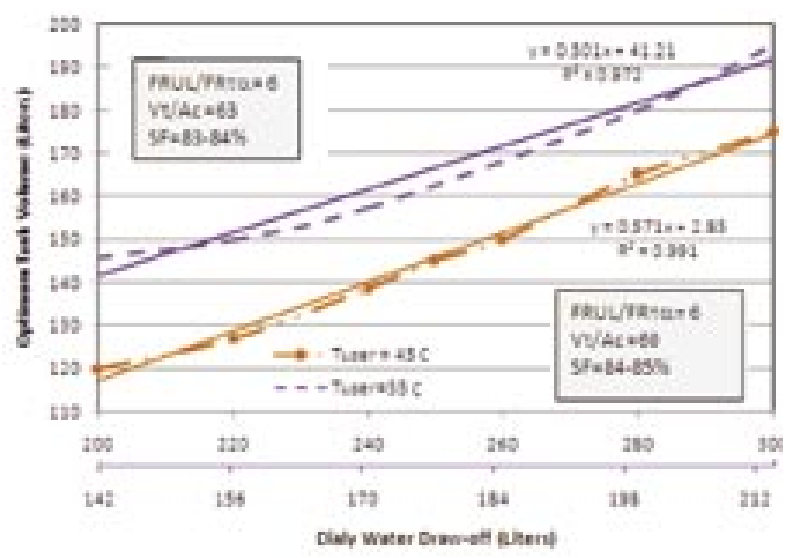

Figure 6: The effect of varying user temperature on the system size

\subsection{Effect of Auxiliary Set Point \\ Temperature}

The auxiliary set point temperature is the main control of the temperature of the water in the upper part of the insulated storage tank of the solar system. Putting the set point temperature as minimum as possible will probably enhance the system efficiency and minimize the cost. However, for the health safety requirement it is recommended to heat water up to $60{ }^{\circ} \mathrm{C}$ to avoid grow Legionella that may cause many diseases [7]. In practice, the temperature to the user is controlled by the mixer. Figure 7 illustrates the impact of the auxiliary heater 
setting temperatures $\left(45\right.$ and $60^{\circ} \mathrm{C}$ ) on the system size where the user temperature is kept similar in both cases at $45^{\circ} \mathrm{C}$ and the system solar fraction ranges from $82 \%$ to $84 \%$. It is obvious from the figure that raising the setting temperature without raising the user temperature increases the system collector area by over 1.1 times and the storage tank capacity by an average of over 1.2 times in case of increasing the auxiliary temperature setting from $45^{\circ} \mathrm{C}$ to $60{ }^{\circ} \mathrm{C}$.

In summary, the optimized values of the design parameter tank volume to collector area ratio $\left(V / A_{c}\right)$ of thermosyphon solar water heaters obtained in this study are summarized in Table 2.

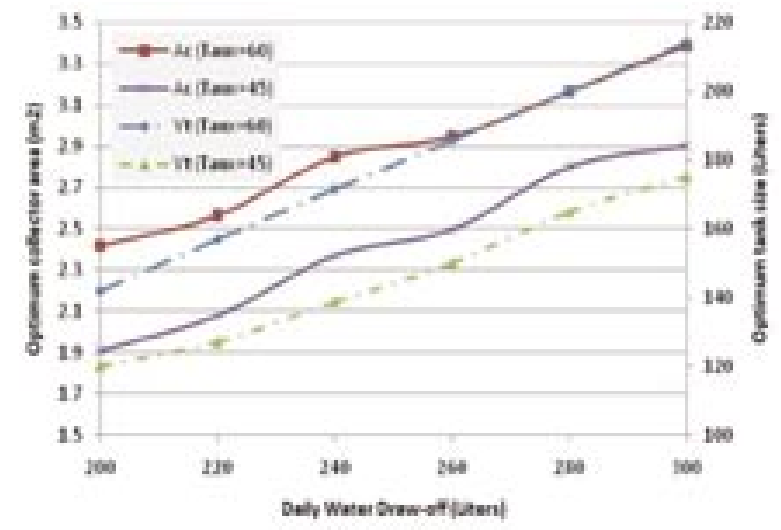

Figure 7: Effect of auxiliary heater set point temperature on the system size $\left(\mathrm{T}_{\text {wer }}-45^{\circ} \mathrm{C}\right)$

It is very clear from the table that at different values of auxiliary set point temperature $\left(\mathrm{T}_{\text {aux }}\right)$ and collector characteristics ratio $F_{R} U_{L} / F_{r}(\tau \alpha)$ there are corresponding values of tank volume to collector area ratio $\left(F_{R} U_{V} / F_{r}(\tau \alpha)\right)$. These values ofcourse vary with the required solar fraction, as mentioned earlier using TrnOpt based on GenOpt in TRNSYS (unconstrained single objective optimization) is not easy to control the solar fraction as in our case where the cost function is chosen as an objective function.

The results have shown that for different tested values of auxiliary set point temperature $\left(\mathrm{T}_{\operatorname{aux}}\right)$ and collector characteristics ratio $\mathrm{F}_{\mathrm{R}} \mathrm{U}_{\mathrm{V}} / \mathrm{F}_{\mathrm{r}}(\tau \alpha)$, the optimum values of the storage tank volume to the collector area are $(49-60)$ liters per square meters. These design values can provide ( 77 to $85 \%$ ) of the system solar fraction.

Table 2: Optimum value of $(\mathrm{V} / \mathrm{Ac})$ at diffenet parameter values

\begin{tabular}{|c|c|c|c|c|}
\hline $\begin{array}{l}\mathrm{T}_{\min } \\
\left({ }^{\circ} \mathrm{C}\right)\end{array}$ & $\begin{array}{l}T_{\text {manr }} \\
\left({ }^{\circ} \mathrm{C}\right)\end{array}$ & SF $(\%)$ & $\mathrm{F}_{\mathrm{R}} \mathrm{U}_{\mathrm{L}} / \mathrm{Fr}(\tau \alpha)$ & $\begin{array}{c}\text { VUAc } \\
\left(\mathbf{L i} \mathbf{m}^{2}\right)\end{array}$ \\
\hline 45 & 45 & 85 & 6 & 60 \\
\hline 60 & 45 & 82 & 6 & 56 \\
\hline 45 & 45 & 82 & 7 & 58 \\
\hline 60 & 45 & 80 & 7 & 51 \\
\hline 45 & 45 & 77 & 8 & 57 \\
\hline 60 & 45 & 78 & 8 & 49 \\
\hline
\end{tabular}

\section{CONCLUSIONS}

The results in this paper demonstrate that the design of thermosyphon solar water heaters involves the interaction of many factors such as operation and weather conditions. All these parameters are unpredictable which varies from place to place as well as, some of them vary from family to another and even from day to day for the same family and for the same place. This of course will make the design problem more complicated. In this paper, typical weather data and typical hot water usage pattern for Tripoli and its suburbs were used for finding the optimum design parameter $\left(V / A_{c}\right)$ of thermosyphon solar water heaters for residential sector.

The study has concluded that the optimum design values $\left(V / A_{c}\right)$ is between $\left(49-60 \mathrm{Lit} / \mathrm{m}^{2}\right)$ for different values of solar fraction, collector characteristics ratio, and auxiliary heater set point temperature.

\section{NOMENCLATURE}

\begin{tabular}{|c|c|}
\hline $\mathrm{Ac}$ & Collector area $\left(\mathrm{m}^{2}\right)$ \\
\hline$C_{\text {A }}$ & $\begin{array}{l}\text { Cost of the collector per unit of area } \\
\left(\text { L.D } / \mathrm{m}^{2}\right)\end{array}$ \\
\hline$C_{y}$ & $\begin{array}{l}\text { Cost of the storage tank per unit of } \\
\text { volume }\left(\mathrm{L} . \mathrm{D} / \mathrm{m}^{3}\right)\end{array}$ \\
\hline$C_{\text {eir }}$ & The cost of the electricity (L.D/kWh) \\
\hline$C_{p}$ & Specific heat of the water $(\mathrm{kJ} / \mathrm{kg} \mathrm{K})$ \\
\hline DIF & Diffuse solar irradiance $\left(\mathrm{kWh} / \mathrm{m}^{2} /\right.$ day $)$ \\
\hline $\mathrm{U}_{\mathrm{U}} / \mathrm{Fr}$ & Collector thermal loss to collect, \\
\hline
\end{tabular}




\begin{tabular}{|c|c|}
\hline$(\tau \alpha)$ & maximum efficiency \\
\hline GR & $\begin{array}{l}\text { Global solar radiation incident on the } \\
\text { surface }\left(\mathrm{kWh} / \mathrm{m}^{2} / \mathrm{day}\right)\end{array}$ \\
\hline $\begin{array}{l}\text { LifeTim } \\
\text { e }\end{array}$ & $\begin{array}{l}\text { Expected life time of the solar system } \\
\text { (year) }\end{array}$ \\
\hline$s_{f}$ & Daily hot water demand (Joule) \\
\hline Que & Annual auxiliary heating rate $(\mathrm{kJ} / \mathrm{hr})$ \\
\hline $\mathrm{SF}$ & System solar fraction \\
\hline $\mathrm{Ta}$ & Ambient tempertaure $\left({ }^{\circ} \mathrm{C}\right)$ \\
\hline $\mathbf{T}_{\operatorname{axx}}$ & $\begin{array}{l}\text { Auxiliray heater set point tempertaure } \\
\left({ }^{\circ} \mathrm{C}\right)\end{array}$ \\
\hline$T_{\text {wnet }}$ & $\begin{array}{l}\text { Desired hot water user tempertautre } \\
\left({ }^{\circ} \mathrm{C}\right)\end{array}$ \\
\hline Y & Storage tank volume (m) \\
\hline is & Wind speed $(\mathrm{m} / \mathrm{s})$ \\
\hline
\end{tabular}

\section{REFERENCES}

[1]. Morrison, G. L. and J. E. Braun, 1985, System modelling and operation characteristics of thermosyphon solar water heaters, Solar Energy, 34, 389405.

[2]. Shariah, A.M. and G. O. G. Löf, 1996, The optimization of tank - volume- to Collector - area ratio for a thermosyphon solar water heater, Renewable Energy, 7, 3 289-300.
[3]. Duffie, J.A., and Beckman, W.A., 1996, Solar Engineering of Thermal Processes, $3^{\text {rd }}$ edition, John Wiley \& Sons, Inc., New Jersey.

[4]. TRNSYS : a transient simulation program version 17.00.0019, Solar Energy Laboratory: Madison University of Wisconsin, USA

[5]. Abdunnabi, M., Loveday DL., and Wright JA., 2008, A design tool for thermosyphon solar water heaters using TRNSYS and genetic algorithms, Universitas 21, Conference on Energy Technologies and Policy, 7-10 September 2008, Birmingham, UK.

[6]. Abdunnabi, M., Solar water heaters field project final report, Centre for Solar Energy Research and Studies, Tajoura-Libya, 2004.

[7]. Marcel Lacroix, Electric water heater designs for load shifting and control of bacterial contamination, Energy Conversion \& Management 40 (1999) 1313-1340 